\title{
The public health implications of farming cattle in areas with high background concentrations of vanadium
}

\author{
B. Gummow ${ }^{\text {a,* }}$, C.J. Botha ${ }^{\text {a }}$, J.P.T.M. Noordhuizen ${ }^{\text {, }}$, \\ J.A.P. Heesterbeek ${ }^{\mathrm{b}}$ \\ ${ }^{\text {a }}$ Faculty of Veterinary Science, University of Pretoria, Private Bag X04, Onderstepoort, \\ Gauteng 0110, South Africa \\ ${ }^{\mathrm{b}}$ Faculty of Veterinary Medicine, University of Utrecht, Yalelaan 7, \\ 3584 CL Utrecht, The Netherlands
}

Received 4 December 2004; received in revised form 8 June 2005; accepted 11 July 2005

\begin{abstract}
Forty-two adult Brahman-cross cattle farmed extensively in two groups, immediately adjacent to and $2 \mathrm{~km}$ from a vanadium processing plant respectively, were slaughtered over a 5 year period at a nearby abattoir. Cattle were being exposed to vanadium at close to no-adverse-effect levels. The dose of vanadium that cattle were taking in prior to slaughter was calculated for each animal from environmental and physiological data using a stochastic risk assessment model. The median exposure doses in the month prior to slaughter ranged from 0.55 to $2.73 \mathrm{mg}$ vanadium $/ \mathrm{kg}$ body weight $/ \mathrm{day}$. A range of tissues was taken from the cattle at slaughter for vanadium determination and tissue levels of vanadium in muscle, liver and kidney are reported. The concentrations of vanadium in the milk of cattle from the same farm sampled over 5 years are also reported. Concentrations were further modelled using a lognormal distribution function to look at possible extreme values that are likely to occur. The concentrations of vanadium in commonly consumed tissues ranged from $<0.05$ to $11.51 \mathrm{mg} / \mathrm{kg}$ (wet-mass basis). The median concentration of vanadium in milk was $0.23 \mathrm{mg}$ vanadium $/ \mathrm{kg}$. People drinking milk were at highest risk. The potential oral daily intake of vanadium for people consuming these foodstuffs was modelled using a stochastic model. The model predicted that there is less than a 5\% chance that the potential daily intake of vanadium from milk will be $>0.44 \mu \mathrm{g} / \mathrm{kg} / \mathrm{day}$ for adults. Based on this upper limit it was concluded from current knowledge of
\end{abstract}

\footnotetext{
* Corresponding author. Tel.: +27 12 5298257; fax: +27 125298315.

E-mail address: bgummow@op.up.ac.za (B. Gummow).
} 
toxicity in humans that the tissue and milk residues from cattle should pose no health risk to the consumer.

(C) 2005 Elsevier B.V. All rights reserved.

Keywords: Environmental epidemiology; Vanadium; Cattle; Meat; Milk; Tissue concentrations; Safety

\section{Introduction}

Vanadium (V) and its biological role and toxicity have been the topic of much research since its discovery in 1869 (reviews: Faulkner Hudson, 1964; Toxicological Profile for Vanadium, 1992; CICAD, 2001; Nriagu, 1998). Yet despite the international interest in vanadium and the amount of research that is being conducted on it, very little work has been done on its effect in ruminants or the effects of long-term exposure in any domestic species or man.

Vanadium is widely distributed in nature (Faulkner Hudson, 1964; Richie, 1985; Waters, 1977) and the prevalence of vanadium exceeds that of such well-known metals as copper and lead (Nriagu, 1998), and equals that of zinc and tin (Byerrum et al., 1974; Windholz, 1983; Grayson, 1983). So, the potential for it to enter the food chain is real. This is enhanced because many fossil fuels contain vanadium - particularly coal (at concentrations of between 19 and $126 \mathrm{ppm}$ in ash) and crude oil (at concentrations of between 3 and $257 \mathrm{ppm}$ ) (Nriagu, 1998).

In man, acute vanadium poisoning results in weakness, nausea, vomiting, anorexia, tinnitus, headache, dizziness, green discolourisation of the tongue, palpitations, transient coronary insufficiency, bradycardia with extra systoles, dermatitis, anaemia, leucopaenia, leukocyte granulation and lowering of cholesterol levels (Faulkner Hudson, 1964; Hunter, 1975; Friberg et al., 1979; Reilly, 1991). People with vanadium concentrations around $14.2 \mu \mathrm{g} / \mathrm{l}$ in urine showed reduced neurobehavioral abilities - particularly so for visuospatial abilities and attention (Toxicological Profile for Vanadium, 1992; SIMRAC, 2000; Barth et al., 2002).

This paper looks at commonly consumed tissues and milk concentrations of vanadium in cattle that were extensively farmed over a 5-year period in an area adjacent to a vanadium processing plant that was known to have higher-than-normal background levels of vanadium. We examined the safety of these concentrations in the light of what is currently known about vanadium toxicity in humans.

\section{Materials and methods}

\subsection{Animal system}

The cattle used in this trial were from a sentinel herd and experimental trial managed by a vanadium mining company and independently monitored by the Section of Epidemiology, Faculty of Veterinary Science, University of Pretoria and the Institute for Soil, Climate and Water (ISCW), Agricultural Research Council, Pretoria. The animal 
model system comprised 30 Brahman-cross females with a 20\% annual replacement, farmed extensively in a 200 ha area adjacent to a vanadium mine. The cattle were purchased in 1999 as pregnant heifers and randomly divided by lottery into two groups: a High-Exposure (HE) Group of 10 and a Low-Exposure (LE) Group of 20 cattle. The HE Group was farmed adjacent to the mine where they were exposed to high background concentrations of vanadium $(\bar{x}=1229 \mathrm{mgV} /$ day $)$. The LE Group was farmed approximately $2-3 \mathrm{~km}$ from the first group in an area where exposure was roughly half that of the HE Group $(\bar{x}=532 \mathrm{mg} \mathrm{V} /$ day). The herd size was limited by the amount of available grazing; stocking density of one animal per 5 ha was used as a guideline. The area where cattle grazed was bushveld and comprised a number of grass species; the predominant ones were a Urochloa species, Aristida congesta, Panicum maximum, Themeda triandra, Heteropogon contortus and Eragrostis rigidior. The only supplemental feeds provided were a commercial winter lick and baled lucern (fed at 3\% body weight/ day), which was fed for approximately 2-3 months during mid-winter (July-September) when the grazing was insufficient to sustain the animals.

\subsection{Observations and analytical procedures}

Cattle in the trial were monitored over a 5-year period and each year non-productive cows or bull calves were slaughtered at a nearby abattoir. Six cohorts of animals were slaughtered over the 5-year period on the following dates; 25 August 1999, 09 February 2001, 06 March 2001, 31 May 2002, 20 June 2003, 07 May 2004. A total of 42 cattle were slaughtered (Table 1). All animals underwent the same slaughter process that was routinely carried out at the abattoir for slaughter of cattle, with the exception that tissue samples were taken from the carcasses as they moved along the slaughter line. Each carcass was inspected by two veterinarians from the Faculty of Veterinary Science, University of Pretoria and the abattoir's meat inspector for lesions or abnormalities. Specific tissues were taken for analysis of vanadium concentrations. Tissues taken for vanadium analysis were approximately $5 \mathrm{~cm} \times 5 \mathrm{~cm}$ in size where possible and were stored in a deep freezer at $-18{ }^{\circ} \mathrm{C}$ prior to analysis. Analysis was carried out within 3 months of the collection of samples.

Vanadium analysis of tissues was done by the ISCW using atomic emission spectrometry (ICP-AES) according to standard internationally accepted methods and quality control procedures (USEPA Standard Methods, 1986). The detection limit for vanadium using the

Table 1

Slaughter dates, exposure group, number and sex of sentinel cattle slaughtered in South Africa on dates shown

\begin{tabular}{lcccc}
\hline Date of slaughter & From high exposure camp & From low exposure camp & Male & Female \\
\hline 25 August 1999 & 0 & 3 & 0 & 3 \\
09 February 2001 & 3 & 2 & 3 & 2 \\
06 March 2001 & 2 & 10 & 3 & 9 \\
31 May 2002 & 2 & 6 & 7 & 1 \\
20 Jun 2003 & 0 & 8 & 4 & 4 \\
07 May 2004 & 3 & 3 & 6 & 0 \\
Total & 10 & 32 & 23 & 19 \\
\hline
\end{tabular}


EPA 3052 method was $0.052 \mathrm{mg} / \mathrm{kg}$. The following tissues were taken for vanadium analysis from animals slaughtered: a caudal coccygeal vertebra, rib-bone, rib-bone biopsy ( $1 \mathrm{~cm}$ diameter $\times 0.5 \mathrm{~cm})$, Musculus iliopsoas (fillet muscle), Musculus triceps brachii (triceps muscle), pars costalis (diaphragmatic muscle), cerebellum, cerebrum, lung (ventral lobe), liver (caudal lobe), kidney, mesenteric lymphnode, spleen, rumen content, testes and whole blood. This paper only reports the findings of muscle, kidney and liver, which are the major components of most diets that include tissues of bovine origin. They are also the benchmark tissues used by most toxicologists for assessing dietary intake of metals.

Eighteen deposit-samplers were placed at strategic points along transections within the camps of the HE and LE Groups to capture airborne particulate matter. Each transect began near the processing plant and extended out to the boundary of the camps. Soil and grass samples were collected once every 3-4 months at the same points as the deposit samples. At the same time, water samples were taken from the drinking troughs. The soil, grass and water samples were analysed by the ISCW, Pretoria, South Africa, for concentrations of heavy metals and in particular vanadium, using standard internationally accepted methods and quality control procedures (Handbook of Standard Soil Testing Methods for Advisory Purposes, 1990). The results of the environmental sampling were used as inputs in a stochastic risk-analysis model described by Gummow et al. (2005), to calculate the exposure doses for the cattle at the time of slaughter.

At the same time the soil and grass samples were taken during the year, milk samples from individual cows were collected for determination of vanadium concentrations in the milk using the same methods as those described above for analysing tissue concentrations of vanadium.

\subsection{Data analysis}

Data was analysed in Microsoft Excel (Version 2000) to establish the concentrations of vanadium in commonly consumed bovine tissues and milk taken from clinically healthy cattle, using descriptive statistical methods. The data was then modelled using a lognormal distribution function defined by the data fitting programme BestFit Version 4.5.2 (Palisade Corporation, USA) and run 10000 times using Latin Hypercube sampling (@ Risk Version 4.5.2, Palisade Corporation, USA) to obtain a range of possible values that could be expected for each tissue and for milk, given the sample size and variability in the data. Ten thousand iterations were run to obtain a smooth distribution curve and the number of iterations exceeded the minimum number required for stability and convergence. A lognormal distribution function was used because it is a distribution function commonly used to describe environmental data (Vose, 2004) and because it consistently fitted the raw data well when the data-fitting programme BestFit Version 4.5.2 (Palisade Corporation, USA) was used.

The potential oral daily intake (PDI) of vanadium by humans consuming animal tissue or milk from cattle farmed in areas high in vanadium was calculated as:

$$
\mathrm{PDI}=\frac{R \times \mathrm{FC}}{\mathrm{BM}}
$$


Table 2

Model outputs for the dose of vanadium each group of South African sentinel cattle was taking in prior to slaughter

\begin{tabular}{|c|c|c|c|c|c|c|c|c|}
\hline & $\begin{array}{l}\text { July } 1999 \text {, } \\
\text { LE }\end{array}$ & $\begin{array}{l}\text { March 2001, } \\
\text { HE }\end{array}$ & $\begin{array}{l}\text { March 2001, } \\
\text { LE }\end{array}$ & $\begin{array}{l}\text { April 2002, } \\
\text { HE }\end{array}$ & $\begin{array}{l}\text { April 2002, } \\
\text { LE }\end{array}$ & $\begin{array}{l}\text { April 2003, } \\
\text { LE }\end{array}$ & $\begin{array}{l}\text { April 2004, } \\
\text { HE }\end{array}$ & $\begin{array}{l}\text { April 2004, } \\
\text { LE }\end{array}$ \\
\hline Total V per day (mg/day) & 552 & 1634 & 579 & 984 & 488 & 405 & 722 & 302 \\
\hline Range (mg V/kg body weight/day) & 6.14 & 35.7 & 4.55 & 12.35 & 4.19 & 6.8 & 6.11 & 2.08 \\
\hline Min (mg V/kg body weight/day) & 0.22 & 0.17 & 0.17 & 0.14 & 0.16 & 0.12 & 0.19 & 0.1 \\
\hline 5 Percentile ( $\mathrm{mg} \mathrm{V/kg}$ body weight/day) & 0.53 & 0.84 & 0.55 & 0.51 & 0.41 & 0.31 & 0.52 & 0.25 \\
\hline 50 Percentile (mg V/kg body weight/day) & 1.18 & 2.73 & 1.2 & 1.44 & 0.88 & 0.75 & 1.19 & 0.55 \\
\hline 95 Percentile (mg V/kg body weight/day) & 2.45 & 8.55 & 2.34 & 4.08 & 1.77 & 1.76 & 2.64 & 1.12 \\
\hline Max (mg V/kg body weight/day) & 6.36 & 35.87 & 4.72 & 12.49 & 4.35 & 6.92 & 6.3 & 2.18 \\
\hline Kurtosis & 5.36 & 13.84 & 4.28 & 9.5 & 5.38 & 9.19 & 5.94 & 4.62 \\
\hline Skewness & 1.17 & 2.5 & 0.96 & 2.02 & 1.17 & 1.66 & 1.36 & 1.04 \\
\hline
\end{tabular}

LE: low exposure group; HE: high exposure group. 
where $R$ is the concentration of vanadium in tissue, FC is the quantity of food (tissue or milk) consumed daily by an adult human with an average body mass (BM) of $60 \mathrm{~kg}$. The FC was based on standard masses of food consumed per day by advantaged people on a western type of diet and is the accepted standard for working out tolerance levels of food residues (Booth and McDonald, 1982). These were $300 \mathrm{~g} /$ day meat, $100 \mathrm{~g} /$ day liver, $50 \mathrm{~g} /$ day kidney and $1.5 \mathrm{l}$ /day milk. Instead of using only the mean tissue concentration of vanadium for $\mathrm{R}$, the lognormal distribution function representing the variability in the concentrations was used. This allowed the PDI to be computed as a distribution function of possible amounts of vanadium that could be consumed per day by the average adult.

\section{Results}

Table 1 gives a summary of when the cattle were slaughtered, the number of cattle slaughtered, their sex and how many of these came from the high, or low exposure area of the trial.

Table 2 gives a summary of the model outputs for the calculated exposure doses at the time of slaughter.

Table 3 summarises the concentration of vanadium found in milk and commonly consumed tissues and the predictions of the lognormal distribution function simulation used to describe each set of data.

Table 4 summarises the distribution functions for PDI of vanadium based on fillet and triceps muscle samples from 39 animals, liver and kidney samples from 42 animals and 139 milk samples taken over a 5-year period.

Table 3

Concentrations of vanadium in tissues and milk (mg/kg wet-mass basis) of South African cattle (1999-2004)

\begin{tabular}{|c|c|c|c|c|c|c|c|c|}
\hline \multirow[t]{2}{*}{ Tissue } & \multicolumn{3}{|c|}{ Measured } & \multicolumn{5}{|c|}{ Lognormal-model prediction } \\
\hline & Min & Median & Max & Min & 5th percentile & 50th percentile & 95th percentile & Max \\
\hline Liver & 0.33 & 1.34 & 11.51 & 0.04 & 0.36 & 1.72 & 8.29 & 68.64 \\
\hline Kidney & 0.22 & 1.09 & 5.37 & 0.07 & 0.39 & 1.42 & 5.19 & 28.31 \\
\hline Fillet & $<0.05$ & 0.28 & 2.55 & 0 & 0.04 & 0.37 & 3.59 & 68.38 \\
\hline Triceps & 0.06 & 0.25 & 1.77 & 0.01 & 0.06 & 0.35 & 2 & 18.23 \\
\hline Milk & $<0.05$ & 0.23 & 1.92 & 0 & 0.02 & 0.18 & 1.75 & 45.79 \\
\hline
\end{tabular}

Table 4

Model outputs for the potential-daily-intake of vanadium in the diet of humans when eating beef or drinking milk in $\mu \mathrm{g}$ vanadium/ $\mathrm{kg}$ body mass/day

\begin{tabular}{lccccr}
\hline & Fillet & Triceps & Liver & Kidney & Milk \\
\hline Min & 0 & 0 & 0.1 & 0.1 & 0 \\
5 Percentile & 0.2 & 0.3 & 0.6 & 0.3 & 0.5 \\
50 Percentile & 1.9 & 1.8 & 2.9 & 1.2 & 4.6 \\
95 Percentile & 18 & 10 & 13.8 & 4.3 & 43.8 \\
Max & 404.5 & 95 & 102.4 & 26.3 & 1639.5 \\
\hline
\end{tabular}




\section{Discussion}

\subsection{Concentration of vanadium in tissue}

Authors vary in what they regard as normal levels of vanadium in individual foods and diets. Nriagu (1998) reports that the range of vanadium in food is between 0.1 and $10 \mu \mathrm{g} /$ $\mathrm{kg}$, with a typical concentration of $1 \mu \mathrm{g} / \mathrm{kg}$. Reilly (1991) on the other hand puts mean levels in a variety of foods to be between 1 and $30 \mu \mathrm{g} / \mathrm{kg}$. While others report that the general foodstuffs do not exceed $1 \mathrm{mg} / \mathrm{kg}$ (Toxicological Profile for Vanadium, 1992). Reilly (1991) goes on to say that meat and fish have a mean concentration of $10 \mu \mathrm{g} / \mathrm{kg}$ with a range of $0-120 \mu \mathrm{g} / \mathrm{kg}$ and milk has a mean concentration of $1 \mu \mathrm{g} / \mathrm{kg}$ with a range of 0 $6 \mu \mathrm{g} / \mathrm{kg}$. Puls (1988), gives a summary of vanadium levels found in cattle, sheep, dogs, pigs, chickens and ducks; normal liver concentrations for cattle are reported as $6-7 \mu \mathrm{g} / \mathrm{kg}$ (wet-mass). These appear to be much lower than the liver concentrations reported for sheep $(100-220 \mu \mathrm{g} / \mathrm{kg})$, dogs $(30-50 \mu \mathrm{g} / \mathrm{kg})$ and chickens $(18-38 \mu \mathrm{g} / \mathrm{kg})$ but of the same order as ducks (0.7-2 $\mu \mathrm{g} / \mathrm{kg}$ ). Hansard et al. (1982a) found that sheep on a basal diet with $2 \mathrm{ppm}$ vanadium contained $0.08 \mathrm{mg} / \mathrm{kg}$ (dry matter basis) vanadium in the muscle, $0.42 \mathrm{mg} / \mathrm{kg}$ in the liver and $0.68 \mathrm{mg} / \mathrm{kg}$ in the kidney.

Gummow et al. (1994) found tissue concentrations of $0.7 \mathrm{mg} / \mathrm{kg}$ (wet-mass) (S.D. $=0.76)$ in the liver and $1.15 \mathrm{mg} / \mathrm{kg}($ S.D. $=1.35)$ in the kidney of cattle (mainly calves) that had shown signs or died of chronic vanadium poisoning. The levels of vanadium in the liver and kidneys of these cattle were generally lower than those described by others for acute and sub-acute vanadium toxicity in sheep and cattle (Faulkner Hudson, 1964; Hansard et al., 1978, 1982a, 1982b; Nechay et al., 1986; Puls, 1988).

The concentrations of vanadium shown in Table 3 are for cattle that were clinically healthy. All their carcasses passed meat inspection, were considered fit for human consumption and showed no obvious macroscopic pathology of any significance. It immediately becomes apparent when looking at the data in Table 3 that these concentrations far exceed what is considered normal by Puls (1988) and also exceed what others consider as the range of concentrations that is typical for foodstuffs. In fact without a history, the concentration of vanadium in these tissues would be consistent with what is reported for ruminants that have clinical signs of vanadium poisoning. Yet, these cattle did not exhibit any clinical signs and ended up in the food chain. Adult cattle in areas high in background vanadium can therefore have much higher concentrations of vanadium in their tissues than was previously thought.

\subsection{Potential daily intake and public health implications}

Estimated oral daily intakes of vanadium by humans are given as 10-30 $\mu \mathrm{g} / \mathrm{day}$ (IPCS, 1988; Reilly, 1991). A UK total diet-study found an intake of $13 \mu \mathrm{g} /$ day in adults (Reilly, 1991) and an Italian study of five towns found the dietary intake to range from 8 to $12 \mu \mathrm{g}$ (Toxicological Profile for Vanadium, 1992); while values of up to $230 \mu \mathrm{g} / \mathrm{day}$ have been reported in Japan (Reilly, 1991). If it is assumed that these values do not take body mass into account, a $60 \mathrm{~kg}$ person would therefore consume between 0.17 and $0.5 \mu \mathrm{g} / \mathrm{kg} / \mathrm{day}$ (using European 10-30 $\mu \mathrm{g} /$ day norm). 
Table 4 shows the daily intake of vanadium when consuming meat, kidney, liver and milk from cattle coming from an area with a high background level of vanadium. The values are roughly 10 times greater than what is considered normal ranges and do not take into account residues in other foodstuffs that might be consumed simultaneously. The chronic dose of vanadium that these cattle were exposed to is close to the no-observedadverse-effect-level (NOAEL) for cattle (Gummow et al., 2005) and therefore constitutes the threshold of a worst-case scenario with respect to healthy cattle slaughtered for human consumption. The simulation model predicts possible extreme values based on the variability of the inputs, which are quite unlikely. The 5th and 95th percentiles therefore, give a better idea of the range within which most values could be expected to occur. From a safety point of view the 95th percentile values would give the best indication of the upper limits of vanadium that could be potentially ingested when consuming tissues from cattle found in areas high in vanadium or when consuming milk from cattle in these areas. From Table 4 it can be seen that the consumption of milk from these areas poses the greatest risk, with a 95th percentile PDI of $44 \mu \mathrm{g} / \mathrm{kg} / \mathrm{day}$. The question that then needs to be answered is whether humans are likely to suffer any adverse effects when consuming vanadium at these concentrations.

A number of oral dose studies have been done in humans over the years. In 1959 five male medical students were dosed 100-125 mg diammonium oxytartratovanadate/day or the equivalent to $1.7 \mathrm{mg} / \mathrm{kg} /$ day (using an average body weight of $70 \mathrm{~kg}$ ), for 6 weeks (Curran et al., 1959). They reportedly showed no adverse clinical signs or haematological changes. In 1962 a group of 12 volunteers received $75 \mathrm{mg}$ diammonium vanadotartrate/day orally for 2 weeks, followed by $125 \mathrm{mg} /$ day for the remaining 5.5 months (Somerville and Davies, 1962). Two subjects withdrew due to "toxic gastrointestinal effects" and five patients had persistent upper abdominal pain, anorexia, nausea and weight loss. Five men developed "green tongue" and one had pharyngitis with marginal ulceration of the tongue. At approximately the same time in another trial, a group of six subjects received 50 $125 \mathrm{mg}$ ammonium vanadyl tartrate/day orally for 45-94 days (Dimond et al., 1963) without apparent harmful effects. One of the most recent studies was a double-blind trial by Fawcett et al. (1996, 1997), which included 11 males and 4 females in the experimental group and 12 males and 4 females in the control placebo group. The experimental group received $0.5 \mathrm{mg}$ vanadyl sulfate $/ \mathrm{kg} /$ day for 12 weeks. No significant differences between the groups in terms of body weight, haematology indices, blood viscosity or standard biochemistry measurements were found. From these studies it is probably safe to assume that an oral dose of $<500 \mu \mathrm{g} / \mathrm{kg} /$ day is likely to have no adverse effects in humans, which is well within the NOAEL of $4.1 \mathrm{mg} \mathrm{V}_{2} \mathrm{O}_{5} / \mathrm{kg} /$ day reported for mice after 2 years of feed exposure (Schroeder and Balassa, 1967). The levels in meat, liver, kidney and milk in this study are therefore well within this margin.

The USA Environmental Protection Agency (EPA) provides a reference dose (Rfd) of $9 \mu \mathrm{g} / \mathrm{kg} /$ day for oral intake of vanadium pentoxide (Toxicological Profile for Vanadium, 1992). A Rfd was defined as "an estimate (with uncertainty spanning perhaps an order of magnitude) of the daily exposure of the human population to a potential hazard that is likely to be without deleterious effects during a lifetime". Given this definition, the Rfd for vanadium pentoxide intake could be defined as a range of $0.9-90 \mu \mathrm{g} / \mathrm{kg} / \mathrm{day}$. This means that the meat, liver, kidney and milk levels all fall within the Rfd given by the EPA as being 
safe for humans. The conclusion therefore, has to be that edible tissues and milk from clinically healthy cattle farmed in areas with high background levels of vanadium (as presented here) are likely to have no adverse effect on human health given the current state of knowledge of vanadium toxicity.

\section{Acknowledgements}

We thank the following people for their various inputs into the project: Dr. D. Holm, Mr. P. Kruger, Dr. W. Schultheiss, Mr. D. Stein, Mr. J.J. van der Merwe.

\section{References}

Barth, A., Schaffer, A.W., Konnaris, C., Blauensteiner, R., Winker, R., Osterode, W., Rudiger, H.W., 2002. Neurobehavioral effects of vanadium. J. Toxicol. Environ. Health Part A 65 (9), 677-683.

Booth, N.H., McDonald, L.E., 1982. Veterinary Pharmacology and Therapeutics, 5th ed. The Iowa State University Press, Ames, Iowa.

Byerrum, R.U., Eckardt, R.E., Hopkins, L.L., et al., 1974. National Academy of Sciences. Vanadium, Washington, DC.

Concise International Chemical Assessment Document (CICAD), 2001. Vanadium pentoxide and other inorganic vanadium compounds. Document Number 29, International Programme on Chemical Safety, INCHEM. http:// www.inchem.org/documents/cicads/cicads/cicad29.htm.

Curran, G., Azarnoff, D., Bolinger, R., 1959. Effect of cholesterol synthesis inhibition in normocholesteraemic young men. J. Clin. Invest. 38, 1251-1261, in CICAD, 2001. Vanadium pentoxide and other inorganic vanadium compounds. Document Number 29, International Programme on Chemical Safety, INCHEM. http:// www.inchem.org/documents/cicads/cicads/cicad29.htm.

Dimond, E., Caravaca, J., Benchimol, A., 1963. Vanadium: excretion, toxicity, lipid effect in man. Am. J. Clin. Nutr. 12, 49-53, in CICAD, 2001. Vanadium pentoxide and other inorganic vanadium compounds. Document Number 29, International Programme on Chemical Safety, INCHEM. http://www.inchem.org/documents/ cicads/cicads/cicad29.htm.

Faulkner Hudson, T.G., 1964. Vanadium: Toxicology and Biological Significance. Elsevier Publishing Company, London.

Fawcett, J., Farquhar, S., Thou, T., Lowe, G., Golding, A., 1996. The effect of oral vanadyl sulphate on body composition and performance in weight-training athletes. Int. J. Sport Nutr. 6, 382-390, in CICAD, 2001. Vanadium pentoxide and other inorganic vanadium compounds. Document Number 29, International Programme on Chemical Safety, INCHEM. http://www.inchem.org/documents/cicads/cicads/cicad29.htm.

Fawcett, J., Farquhar, S., Walker, R., Thou, T., Shand, B., 1997. Oral vanadyl sulphate does not affect blood cells, viscosity or biochemistry in humans. Pharmacol. Toxicol. 80, 202-206, in CICAD, 2001. Vanadium pentoxide and other inorganic vanadium compounds. Document Number 29, International Programme on Chemical Safety, INCHEM. http://www.inchem.org/documents/cicads/cicads/cicad29.htm.

Friberg, L., Nordberg, G.F., Vouk, V.B. (Eds.), 1979. Handbook on the Toxicology of Metals. Elsevier/NorthHolland Biomedical Press, Amsterdam.

Grayson, M., 1983. Kirk-Othmer Encyclopaedia of Chemical Technology, 3rd ed, 23. John Wiley and Sons, New York, pp. 688-704.

Gummow, B., Bastianello, S.S., Botha, C.J., Smith, H.J.C., Basson, A.J., Wells, B., 1994. Vanadium air pollution: a cause of malabsorption and immunosuppression in cattle. Onderstepoort J. Vet. Res. 61, 303-316.

Gummow, B., Kirsten, W.F.A., Gummow, R.J., Heesterbeek, J.A.P., 2005. A stochastic model for estimating intake of vanadium by beef cattle used as sentinels within the vanadium mining industry. Prevent. Vet. Med., submitted for publication.

Handbook of Standard Soil Testing Methods for Advisory Purposes, 1990. Soil Science Society of South Africa, Sunnyside, Pretoria, Republic of South Africa. 
Hansard, S.L., Ammerman, C.B., Fick, K.R., Miller, S.M., 1978. Performance and vanadium content of tissues in sheep as influenced by dietary vanadium. J. Anim. Sci. 46, 1091-1095.

Hansard, S.L., Ammerman, C.B., Henry, P.R., Simpson, C.F., 1982a. Vanadium metabolism in sheep. 1. Comparative and acute toxicity of vanadium compounds in sheep. J. Anim. Sci. 55, 344-349.

Hansard, S.L., Ammerman, C.B., Henry, P.R., 1982b. Vanadium metabolism in sheep. II. Effect of dietary vanadium on performance, vanadium excretion and bone deposition in sheep. J. Anim. Sci. 55, 350-356.

Hunter, D., 1975. The Diseases of Occupations. The English Universities Press Ltd., St. Paul's House, Warwick Lane, London.

IPCS, 1988. Vanadium. WHO, Geneva. International Programme on Chemical Safety, 170 pp., in CICAD, 2001. Vanadium pentoxide and other inorganic vanadium compounds. Document Number 29, International Programme on Chemical Safety, INCHEM. http://www.inchem.org/documents/cicads/cicads/cicad29.htm.

Nechay, B.R., Nanninga, L.B., Nechay, P.S.E., Post, R.L., Grantham, J.J., Macara, I.G., Kubena, L.F., Phillips, T.D., Nielsen, F.H., 1986. Role of vanadium in biology. Fed. Proc. 42 (2), 123-124.

Nriagu, J.O., 1998. Vanadium in the Environment. John Wiley and Sons, New York.

Puls, R., 1988. Mineral Levels in Animal Health: Diagnostic Data. Sherpa International Clearbrook, BC, Canada.

Reilly, C., 1991. Metal Contamination of Food, 2nd ed. Elsevier Applied Science, New York.

Richie, D.A., 1985. The effects of toxicity induced by feeding selected elements ( $\mathrm{Pb}, \mathrm{Hg}, \mathrm{Cd}, \mathrm{F}, \mathrm{V})$. Agri-Practice $6(1), 37-42$.

Schroeder, H.A., Balassa, J.J., 1967. Arsenic, germanium, tin and vanadium in mice: effects on growth, survival and tissue levels. J. Nutr. 92, 245-252, in “Toxicological Profile for Vanadium”, 1992. US Department of Health and Human Services, Public Health Service, Agency for Toxic Substances and Disease Registry, TP$91 / 29$.

SIMRAC (Safety in Mines Research Advisory Committee Report), September 2000. Hazardous metals in mining processing plants in South Africa. The risk of occupational exposure. Mine Health and Safety Council.

Somerville, J., Davies, B., 1962. Effect of vanadium on serum cholesterol. Am. Heart J. 64(1), 54-56, in CICAD, 2001. Vanadium pentoxide and other inorganic vanadium compounds. Document Number 29, International Programme on Chemical Safety, INCHEM. http://www.inchem.org/documents/cicads/cicads/cicad29.htm.

Toxicological Profile for Vanadium, 1992. US Department of Health and Human Services, Public Health Service, Agency for Toxic Substances and Disease Registry, TP-91/29.

USEPA Standard Methods, 1986. Environmental Protection Agency. Test methods for evaluating solid waste, physical/chemical methods (SW-846): Method 3050 Acid digestion of sediments, sludges and soils. USA Environmental Protection Agency, Washington, DC.

USEPA Standard Methods, 1996. Environmental Protection Agency. Test methods for evaluating solid waste, physical/chemical methods: Method 3052, Microwave assisted acid digestion of siliceous and organically based matrices. USA Environmental Protection Agency, Washington, DC.

Vose Consulting, 2004. ModelAssist for @ Risk, Risk Thinking, Ltd. http://www.risk-modelling.com.

Waters, M.D., 1977. Toxicology of vanadium. Adv. Mod. Toxicol. 2, 147-189.

Windholz, M. (Ed.), 1983. The Merck Index, 10th ed, vol. 82.Merck and Co., Inc., Rahway, NJ, 1417-1419. 